\title{
Impact of cardiovascular disease and cardiovascular risk factors in hospitalised COVID-19 patients
}

\author{
L. S. D. Jewbali · J. Hoogervorst-Schilp · E. Belfroid · C. W. Jansen · F. W. Asselbergs · H. J. Siebelink
}

Accepted: 31 March 2021 / Published online: 16 April 2021

(C) The Author(s) 2021

\begin{abstract}
Background Hospitalised COVID-19 patients with underlying cardiovascular disease (CVD) and cardiovascular risk factors appear to be at risk of poor outcome. It is unknown if these patients should be considered a vulnerable group in healthcare delivery and healthcare recommendations during the COVID19 pandemic.

Methods A systematic literature search was performed to answer the following question: In which hospitalised patients with proven COVID-19 and with underlying CVD and cardiovascular risk factors should doctors be alert to a poor outcome? Relevant outcome measures were mortality and intensive care unit admission. Medline and Embase databases were searched using relevant search terms until 9 June
\end{abstract}

\section{Supplementary Information The online version of this article (https://doi.org/10.1007/s12471-021-01572-9) contains supplementary material, which is available to authorized users.}

\section{S. D. Jewbali $(\bowtie)$}

Department of Cardiology and Intensive Care Medicine, Erasmus University Medical Center, Rotterdam, The Netherlands

1.jewbali@erasmusmc.nl

J. Hoogervorst-Schilp $\cdot$ E. Belfroid

Knowledge Institute of Medical Specialists, Utrecht, The Netherlands

\section{W. Jansen}

Netherlands Society of Cardiology, Utrecht, The Netherlands

F. W. Asselbergs

Department of Cardiology, University Medical Center

Utrecht, Utrecht, The Netherlands

H. J. Siebelink

Department of Cardiology, Leiden University Medical

Center, Leiden, The Netherlands
2020. After systematic analysis, 8 studies were included.

Results Based on the literature search, there was insufficient evidence that CVD and cardiovascular risk factors are significant predictors of mortality and poor outcome in hospitalised patients with COVID19. Due to differences in methodology, the level of evidence of all studies was graded 'very low' according to the Grading Recommendations Assessment, Development and Evaluation methodology. It is expected that in the near future, two multinational and multicentre European registries (CAPACITY-COVID and LEOSS) will offer more insight into outcome in COVID-19 patients.

Conclusion This literature review demonstrated there was insufficient evidence to identify CVD and cardiovascular risk factors as important predictors of poor outcome in hospitalised COVID-19 patients. However, patients with CVD and cardiovascular risk factors remain vulnerable to infectious disease outbreaks. As such, governmental and public health COVID-19 recommendations for vulnerable groups apply to these patients.

Keywords COVID-19 - Cardiovascular risk . Cardiovascular disease $\cdot$ Outcome

\section{Clinical question}

In which hospitalised patients with proven COVID-19 and with underlying cardiovascular disease and cardiovascular risk factors should doctors be alert to a poor outcome?

\section{Introduction}

Hospitalised COVID-19 patients with pre-existing cardiovascular disease (CVD) and risk factors for CVD 
seem to have a worse outcome. CVD risk factors appear to affect the immune function and thus relate indirectly to the prognosis in COVID-19 patients [1, 2]. Identifying COVID-19 patients at risk of worse outcome can tailor healthcare delivery and healthcare measures such as vaccination policy. It can also increase patient awareness regarding risk factors for COVID-19.

\section{Methods}

A review of the literature was performed to answer the following question: Which independent prognostic factors (cardiovascular risk factors or CVD) strongly predict a poor outcome of COVID-19, independent of other factors? This question was structured in PICO format.

Population: All patients with proven COVID-19

Intervention: Presence of one of the following prognostic factors: cardiovascular risk factors such as smoking, obesity, hypercholesterolaemia, hypertension, diabetes mellitus (insulin resistance, non-alcoholic steatohepatitis), CVD, cardiovascular history (arrhythmias, coronary artery disease, heart failure, valvular heart disease)

Comparison: Absence of the prognostic factors Outcome: $\quad$ Mortality (crucial), intensive care unit (ICU) admission (crucial), hospital admission, length of stay, thromboembolic complications (pulmonary embolism, stroke, transient ischaemic attack)

Timing: Admission to hospital, admission to ICU, during hospital stay, at home

Setting: In-hospital, pre-hospital

Confounder: Age

\section{Relevant outcome measures}

Mortality and ICU admission were considered critical outcome measures for decision-making, whereas the other outcome measures were considered important outcome measures. Definitions of outcome measures from the studies were used. Minimal clinically relevant differences for the outcome measures were not defined.

\section{Search and select}

The databases Medline (via Ovid) and Embase (via www.embase.com) were searched using relevant search terms until 9 June 2020. The systematic literature search resulted in 567 hits (see Table S1 in the Electronic Supplementary Material for search strategy). We did not find any studies investigating the impact of a multivariable cardiovascular prognostic model. Studies developing and/or validat- ing a multivariable prognostic model were selected based on the following criteria: systematic review, randomised controlled trial or observational study (cohort study) assessing the longitudinal relation between cardiovascular risk factors (smoking, obesity, hypercholesterolaemia, hypertension, diabetes mellitus), CVD and cardiovascular history (measured at hospital admission/during hospital stay) with mortality, ICU admission, hospital admission, length of stay, thromboembolic complications (measured at endpoint) in patients with proven COVID-19. Age was considered a confounder that had to be included in the multivariable models.

Initially, 45 studies were selected based on title and abstract screening. After reading the full text, 37 studies were excluded (excluded studies are listed in Table S2 in the Electronic Supplementary Material), resulting in the inclusion of 8 studies in the literature review. A brief overview of study characteristics of the included studies is shown in Tab. 1. The assessment of the risk of bias is summarised in the risk of bias table (see Table S3 in the Electronic Supplementary Material). In many studies, populations, measurement of factors and selection methods of factors were not well described.

The level of evidence was assessed according to the Grading Recommendations Assessment, Development and Evaluation (GRADE) methodology (www. gradeworkinggroup.org).

\section{Description of studies}

Chen [3], Giacomelli [4] and Wang [5] assessed candidate factors during hospital stay and mortality as endpoint. Cummings [6], Gao [7], Klang [8] and Palaiodimos [9] assessed candidate factors during hospital stay and in-hospital mortality as endpoint. Petrilli [10] assessed candidate factors during hospital stay and discharge to hospice or death among those patients admitted to hospital as endpoint. Multivariable models showing associations between predefined candidate prognostic factors and outcome were reported. Only Chen [3] internally validated the risk factors by establishing a nomogram based on the results of the multivariate analysis. It was decided to include non-validated studies in the literature review for this outcome as well, as risk of bias was moderate in the study by Chen.

\section{Results}

All studies described models predicting mortality. Only Petrilli [10] also reported on a model predicting hospital admission. Tab. 2 shows the 8 model designs. The selected studies did not report on the prespecified outcome measures ICU admission, in-hospital length of stay and thromboembolic complications. Therefore, apart from mortality, other outcomes cannot be described. 
Table 1 Study characteristics of included studies

\begin{tabular}{|c|c|c|c|c|c|c|c|}
\hline $\begin{array}{l}\text { Study (first } \\
\text { author name, } \\
\text { reference) }\end{array}$ & Population & $N$ & $\begin{array}{l}\text { Age in years; } \\
\text { median (IQR) }\end{array}$ & Inclusion period & Follow-up & Method & Outcome \\
\hline Chen [3] & $\begin{array}{l}\text { Hospitalised } \\
\text { COVID-19 patients, } \\
575 \text { hospitals, } \\
\text { China }\end{array}$ & 1590 & Not reported & $\begin{array}{l}\text { Admission to hospital } \\
\text { until } 31 \text { Jan } 2020 \\
\text { (time of admission to } \\
\text { hospital not reported) }\end{array}$ & Not reported & $\begin{array}{l}\text { Multivariate Cox regression model; } \\
\text { included prognostic factors selected } \\
\text { based on univariable analyses; } \\
\text { nomogram developed based on } \\
\text { backward step-down selection }\end{array}$ & Mortality \\
\hline Cummings [6] & $\begin{array}{l}\text { Hospitalised } \\
\text { COVID-19 patients } \\
\text { ( } \geq 18 \text { years), criti- } \\
\text { cally ill with acute } \\
\text { hypoxaemic res- } \\
\text { piratory failure, } \\
2 \text { hospitals, USA }\end{array}$ & 257 & $62(51-72)$ & $\begin{array}{l}\text { Admission to hospital } \\
\text { between } 2 \text { Mar-1 Apr } \\
2020 \text {; candidate fac- } \\
\text { tors measured during } \\
\text { hospital stay (col- } \\
\text { lected from medical } \\
\text { records) }\end{array}$ & 28 Apr 2020 & $\begin{array}{l}\text { Multivariate Cox regression model; } \\
\text { included prognostic factors consid- } \\
\text { ered relevant to in-hospital mortality } \\
\text { by the authors }\end{array}$ & $\begin{array}{l}\text { In-hospital } \\
\text { mortality }\end{array}$ \\
\hline Gao [7] & $\begin{array}{l}\text { Hospitalised } \\
\text { COVID-19 patients, } \\
1 \text { hospital, China }\end{array}$ & 2877 & $\begin{array}{l}\text { Not reported } \\
\text { for total group }\end{array}$ & $\begin{array}{l}\text { Admission to hospital } \\
\text { between } 5 \text { Feb-15 } \\
\text { Mar 2020; candidate } \\
\text { factors measured } \\
\text { during hospital stay } \\
\text { (collected from medi- } \\
\text { cal records) }\end{array}$ & 1 Apr 2020 & $\begin{array}{l}\text { Multivariable Cox proportional haz- } \\
\text { ards model; reason of selection of } \\
\text { included prognostic factors in multi- } \\
\text { variable model not described }\end{array}$ & $\begin{array}{l}\text { In-hospital } \\
\text { mortality }\end{array}$ \\
\hline Giacomelli [4] & $\begin{array}{l}\text { Hospitalised } \\
\text { COVID-19 patients } \\
\text { ( } \geq 18 \text { years), } 1 \text { hos- } \\
\text { pital, Italy }\end{array}$ & 233 & $61(50-72)$ & $\begin{array}{l}\text { Admission to hos- } \\
\text { pital between } \\
21 \text { Feb-19 Mar } \\
2020 ; \text { candidate fac- } \\
\text { tors measured during } \\
\text { hospital stay (col- } \\
\text { lected from medical } \\
\text { records) }\end{array}$ & 20 Apr 2020 & $\begin{array}{l}\text { Multivariable Cox proportional haz- } \\
\text { ards model; included prognostic } \\
\text { factors selected based on univariable } \\
\text { analyses }\end{array}$ & Mortality \\
\hline Klang [8] & $\begin{array}{l}\text { Hospitalised } \\
\text { COVID-19 patients } \\
\text { ( } \geq 18 \text { years), } 5 \text { hos- } \\
\text { pitals, USA }\end{array}$ & 3406 & $\begin{array}{l}\text { Not reported } \\
\text { for total group }\end{array}$ & $\begin{array}{l}\text { Admission to hos- } \\
\text { pital between } \\
1 \text { Mar-17 May 2020; } \\
\text { candidate factors } \\
\text { measured during } \\
\text { hospital stay (col- } \\
\text { lected from medical } \\
\text { records) }\end{array}$ & Not reported & $\begin{array}{l}\text { Multivariable logistic regression } \\
\text { model, adjusted for age decile, male } \\
\text { sex, CAD, CHF, hypertension, DM, } \\
\text { hyperlipidaemia, CKD, history of can- } \\
\text { cer, smoking (past or present), BMI } \\
30-40 \mathrm{~kg} / \mathrm{m}^{2}, \mathrm{BMl} \geq 40 \mathrm{~kg} / \mathrm{m}^{2} \text { and } \\
\text { race; included prognostic factors se- } \\
\text { lected based on univariable analyses; } \\
\text { no validation reported }\end{array}$ & $\begin{array}{l}\text { In-hospital } \\
\text { mortality }\end{array}$ \\
\hline Palaiodimos [9] & $\begin{array}{l}\text { Hospitalised } \\
\text { COVID-19 patients, } \\
1 \text { hospital, USA }\end{array}$ & 200 & $64(50-73.5)$ & $\begin{array}{l}\text { Admission to hospital } \\
\text { between 9-22 Mar } \\
\text { 2020; candidate fac- } \\
\text { tors measured during } \\
\text { hospital stay (col- } \\
\text { lected from medical } \\
\text { records) }\end{array}$ & $\begin{array}{l}\text { 3-weeks } \\
\text { follow-up: } \\
12 \text { Apr } 2020\end{array}$ & $\begin{array}{l}\text { Multivariate logistic regression } \\
\text { model; } 3 \text { models used (model 1: } \\
\text { BMl and age; model 2: all variables } \\
\text { with significant univariate associa- } \\
\text { tions; model 3: variables of model } 2 \\
\text { plus clinically significant variables } \\
\text { that did not show a significant uni- } \\
\text { variate association); no validation } \\
\text { reported }\end{array}$ & $\begin{array}{l}\text { In-hospital } \\
\text { mortality }\end{array}$ \\
\hline Petrilli [10] & $\begin{array}{l}\text { Admitted to hospital } \\
\text { and non-admitted } \\
\text { COVID- } 19 \text { patients, } \\
>260 \text { outpatient } \\
\text { office sites and } 4 \\
\text { acute care hospi- } \\
\text { tals, USA }\end{array}$ & $\begin{array}{l}5279 \\
(2441 \\
\text { admit- } \\
\text { ted to } \\
\text { hospital) }\end{array}$ & $\begin{array}{l}\text { Tested pop- } \\
\text { ulation: } 54 \\
\text { (38-66); } \\
\text { admitted pop- } \\
\text { ulation: } 63 \\
\text { (51-74) }\end{array}$ & $\begin{array}{l}\text { Patients tested be- } \\
\text { tween } 1 \text { Mar- } 8 \text { Apr } \\
\text { 2020; candidate fac- } \\
\text { tors measured during } \\
\text { hospital stay (col- } \\
\text { lected from medical } \\
\text { records) }\end{array}$ & 5 May 2020 & $\begin{array}{l}\text { Multivariable logistic regression } \\
\text { model; predictors selected based } \\
\text { on published literature and authors' } \\
\text { clinical experience with COVID-19 } \\
\text { patients }\end{array}$ & $\begin{array}{l}\text { Inpatient hospi- } \\
\text { tal admission, } \\
\text { discharge to } \\
\text { hospice or death } \\
\text { among those } \\
\text { admitted to } \\
\text { hospital }\end{array}$ \\
\hline Wang [5] & $\begin{array}{l}\text { Hospitalised } \\
\text { COVID-19 patients } \\
\text { ( }>60 \text { years), } 1 \text { hos- } \\
\text { pital, China }\end{array}$ & 339 & $69(65-76)$ & $\begin{array}{l}\text { Admission to hospital } \\
\text { between } 1 \text { Jan- } 6 \text { Feb } \\
2020 \text {; candidate fac- } \\
\text { tors measured during } \\
\text { hospital stay (col- } \\
\text { lected from medical } \\
\text { records) }\end{array}$ & $\begin{array}{l}4 \text { weeks from } \\
\text { last admission }\end{array}$ & $\begin{array}{l}\text { Multivariate Cox regression model; } \\
\text { included prognostic factors selected } \\
\text { based on univariable analyses; no } \\
\text { validation reported }\end{array}$ & Mortality \\
\hline
\end{tabular}

IQR interquartile range, $C A D$ coronary artery disease, $C H F$ congestive heart failure, $D M$ diabetes mellitus, $C K D$ chronic kidney disease, $B M I$ body mass index 
Table 2 Reported prognostic models for mortality

\begin{tabular}{|c|c|c|c|}
\hline $\begin{array}{l}\text { Study (first author } \\
\text { name, reference) }\end{array}$ & $\begin{array}{l}\text { Mortality }(n / N \\
(\%))\end{array}$ & Outcome & Included prognostic factors \\
\hline Chen [3] & $\begin{array}{l}50 / 1590 \\
(3.1 \%)\end{array}$ & Mortality & $\begin{array}{l}\text { Age, coronary heart disease, cerebrovascular disease, dyspnoea, procalcitonin, } \\
\text { aspartate aminotransferase, total bilirubin, creatinine }\end{array}$ \\
\hline Cummings [6] & $\begin{array}{l}101 / 257 \\
(39.0 \%)\end{array}$ & $\begin{array}{l}\text { Time from hospital admission to } \\
\text { in-hospital mortality }\end{array}$ & $\begin{array}{l}\text { Age, sex, symptom duration before hospital presentation, hypertension, chronic } \\
\text { cardiac disease, COPD, DM, IL-6 concentrations, D-dimer concentrations }\end{array}$ \\
\hline Gao [7] & $\begin{array}{l}56 / 2877 \\
(1.9 \%)\end{array}$ & $\begin{array}{l}\text { All-cause mortality during hospitaliza- } \\
\text { tion }\end{array}$ & $\begin{array}{l}\text { Hypertension, age, sex, DM, myocardial infarction, treatment with } \mathrm{PCl} \text { or CABG, } \\
\text { renal failure, chronic heart failure, asthma, COPD, stroke }\end{array}$ \\
\hline Giacomelli [4] & $\begin{array}{l}48 / 233 \\
(20.6 \%)\end{array}$ & $\begin{array}{l}\text { Mortality (censoring date: } 20 \mathrm{Apr} \\
\text { 2020) }\end{array}$ & $\begin{array}{l}\text { Age, sex, obesity, being treated with } \geq 1 \text { antihypertensive agent, disease severity, } \\
\text { presence of anaemia, lymphocyte count, D-dimer, C-reactive protein, creatinine, } \\
\text { creatine kinase }\end{array}$ \\
\hline Klang [8] & $\begin{array}{l}1136 / 3406 \\
(33.4 \%)\end{array}$ & In-hospital mortality & $\begin{array}{l}\text { Age, sex, comorbidities (CAD, CHF, hypertension, DM, hyperlipidaemia, CKD, can- } \\
\text { cer), obesity, smoking status }\end{array}$ \\
\hline Palaiodimos [9] & $\begin{array}{l}48 / 200 \\
(24 \%)\end{array}$ & In-hospital mortality & $\begin{array}{l}\text { Age, BMl, heart failure, CAD, DM, CKD or end-stage renal disease, COPD, current } \\
\text { or former smoker }\end{array}$ \\
\hline Petrilli [10] & $\begin{array}{l}665 / 2741 \\
(24.3 \%)\end{array}$ & $\begin{array}{l}\text { (1) Admission to hospital } \\
\text { (2) Mortality (only admitted patients in } \\
\text { analysis) }\end{array}$ & $\begin{array}{l}\text { Age, BMI, sex, ethnicity, smoking status, CAD, heart failure, hypertension, DM, } \\
\text { asthma or COPD, CKD, cancer }\end{array}$ \\
\hline Wang [5] & $\begin{array}{l}65 / 339 \\
(19.2 \%)\end{array}$ & Mortality & Age, CVD, cerebrovascular disease, COPD \\
\hline
\end{tabular}

\section{Mortality predicted by prognostic factors measured during hospital stay}

As the reported models included different outcome measures and different prognostic factors, results could not be pooled. Because the models were not validated, only results regarding factors included in at least two studies are discussed. Tab. 3 shows the relevance of the reported associations for mortality.

\section{Body mass index}

Starting with a high level of evidence for prognostic studies, the level of evidence regarding the outcome measure mortality was downgraded by one level because of risk of bias (some patients still under treatment at end of study), by one level because of indirectness (studies not validated) and by one level for imprecision (wide confidence intervals) to 'very low'.

\section{Smoking}

Starting with a high level of evidence for prognostic studies, the level of evidence regarding the outcome measure mortality was downgraded by one level because of risk of bias (some patients still under treatment at end of study), by one level because of indirectness (studies not validated) and by one level for imprecision (wide confidence intervals) to 'very low'.

\section{Hypertension}

Starting with a high level of evidence for prognostic studies, the level of evidence regarding the outcome measure mortality was downgraded by one level because of risk of bias (some patients still under treatment at end of study), by one level because of indirectness (studies not validated) and by one level for imprecision (wide confidence intervals, too many prognos- tic factors included in relation to number of events) to 'very low'.

\section{Diabetes mellitus}

Starting with a high level of evidence for prognostic studies, the level of evidence regarding the outcome measure mortality was downgraded by one level because of risk of bias (some patients still under treatment at end of study), by one level because of indirectness (studies not validated) and by one level for imprecision (wide confidence intervals) to 'very low'.

\section{Coronary artery disease or congestive heart failure}

Starting with a high level of evidence for prognostic studies, the level of evidence regarding the outcome measure mortality was downgraded by one level because of risk of bias (some patients still under treatment at end of study), by one level because of indirectness (studies not validated) and by one level because of inconsistency of results to 'very low'.

\section{Cerebrovascular disease}

Starting with a high level of evidence for prognostic studies, the level of evidence regarding the outcome measure mortality was downgraded by one level because of risk of bias (some patients still under treatment at end of study), by one level because of indirectness (studies not validated), by one level because of inconsistency of results and by one level because of imprecision (low number of included patients) to 'very low'.

\section{Heart failure}

Starting with a high level of evidence for prognostic studies, the level of evidence regarding the outcome measure mortality was downgraded by one level be- 


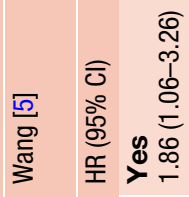

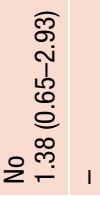

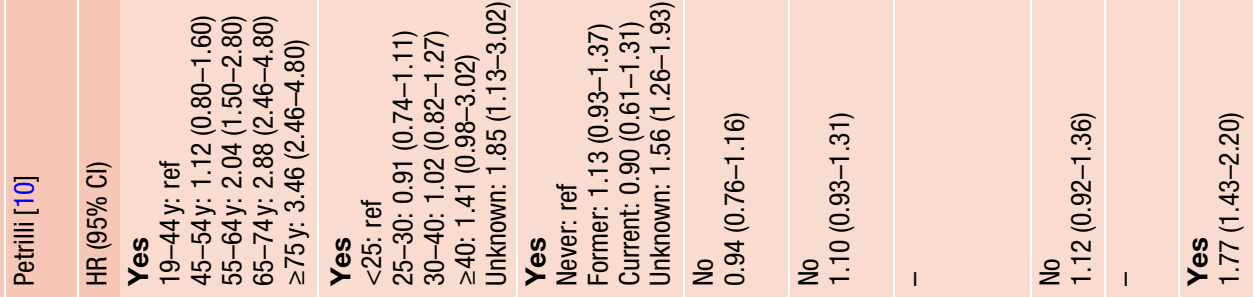
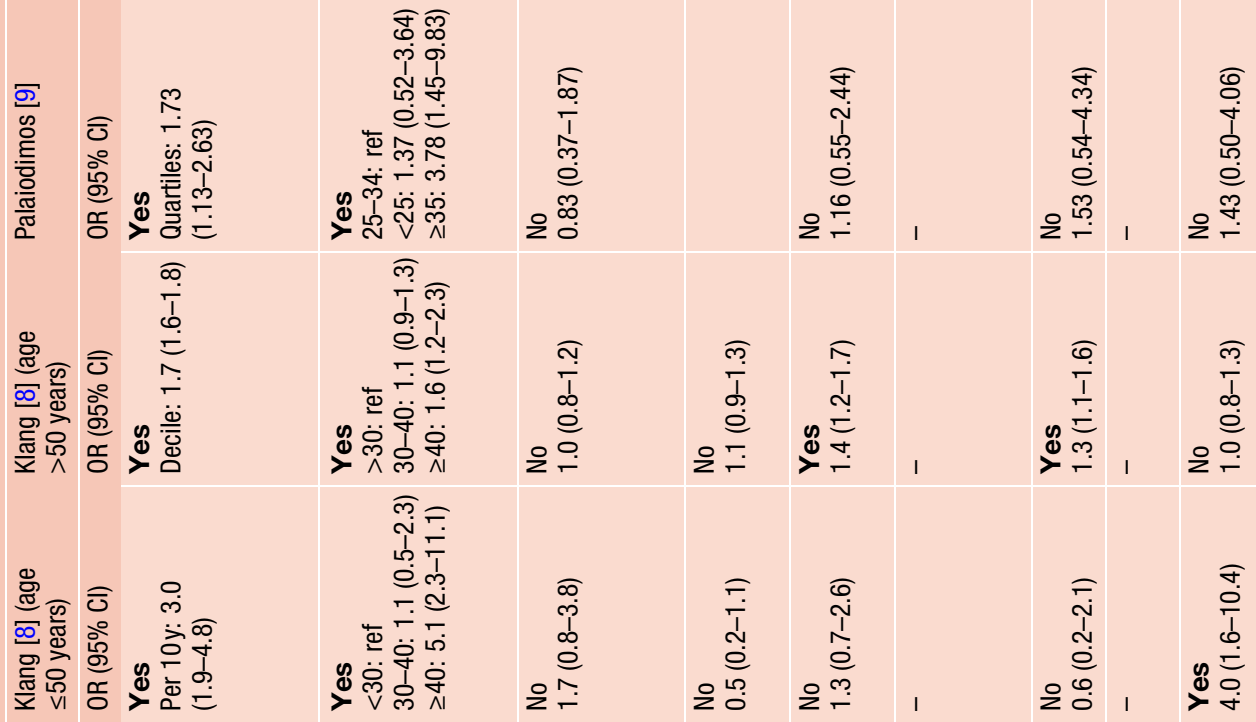

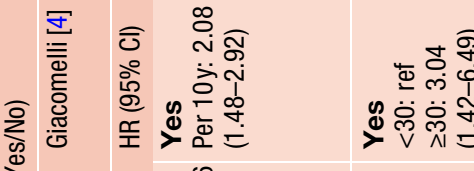

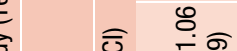

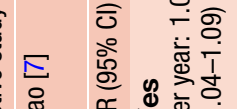

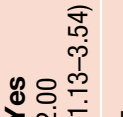

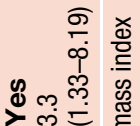

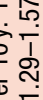

\section{这宗}

원웡
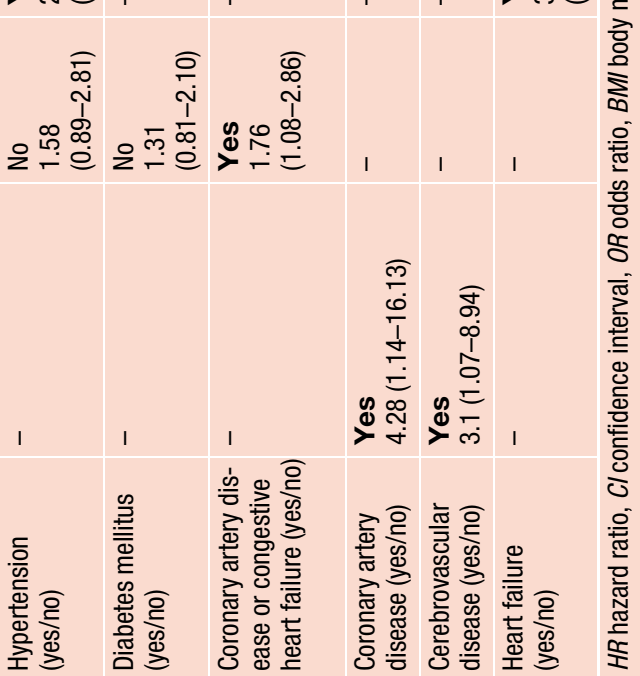

$\frac{\sqrt{2}}{\frac{0}{0}}$

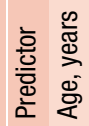

$\frac{\sqrt{0}}{\sum_{\overline{0}}^{2}}$
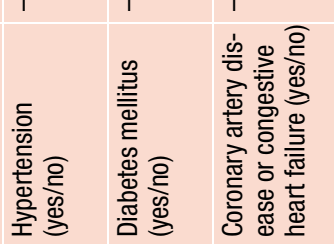

$\stackrel{5}{\stackrel{5}{\sim}}$

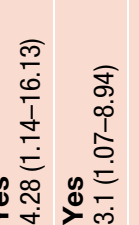

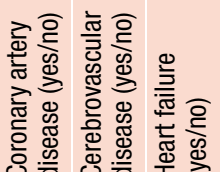

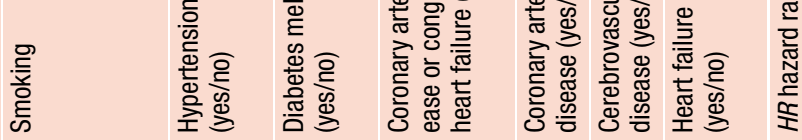


cause of risk of bias (some patients still under treatment at end of study), by one level because of indirectness (studies not validated), by one level because of inconsistency of results and by one level because of imprecision (low number of included patients) to 'very low'.

\section{Conclusion}

Mortality predicted by prognostic factors measured during hospital stay

\section{Body mass index}

It is unsure whether body mass index (BMI) is a predictor of mortality in COVID-19 patients admitted to hospital, adjusted for age. Sources: Cummings, Giacomelli, Klang, Palaiodimos, Petrilli (very low GRADE level).

\section{Smoking}

It is unsure whether smoking is a predictor of mortality in COVID-19 patients admitted to hospital, adjusted for age. Sources: Klang, Palaiodimos, Petrilli (very low GRADE level).

\section{Hypertension}

It is unsure whether hypertension is a predictor of mortality in COVID-19 patients admitted to hospital, adjusted for age. Sources: Cummings, Gao, Klang, Petrilli (very low GRADE level).

\section{Diabetes mellitus}

It is unsure whether diabetes is a predictor of mortality in COVID-19 patients admitted to hospital, adjusted for age. Sources: Cummings, Klang, Palaiodimos, Petrilli (very low GRADE level).

\section{Coronary artery disease}

It is unsure whether coronary artery disease or congestive heart failure is a predictor of mortality in COVID-19 patients admitted to hospital, adjusted for age. Sources: Chen, Cummings, Klang, Palaiodimos, Petrilli (very low GRADE level).

\section{Cerebrovascular disease}

It is unsure whether cerebrovascular disease is a predictor of mortality in COVID-19 patients admitted to hospital, adjusted for age. Sources: Chen, Wang (very low GRADE level).

\section{Heart failure}

It is unsure whether heart failure is a predictor of mortality in COVID-19 patients admitted to hospital, adjusted for age. Sources: Klang, Palaiodimos, Petrilli (very low GRADE level).
Other cardiovascular risk factors, cardiovascular disease or cardiovascular history

We cannot conclude which other cardiovascular risk factors, CVD or cardiovascular history can predict hospital admission or mortality in COVID-19 patients due to a lack of studies on multivariable models taking age into account (no GRADE level).

In conclusion, based on this literature review, there was insufficient evidence that underlying CVD and cardiovascular risk factors are predictors of mortality in hospitalised COVID-19 patients. Populations, measurement of factors and selection methods of factors were not well described in many studies. Even though BMI could statistically be considered a risk factor for mortality, this was not supported by the level of evidence. Risk of bias, indirectness and imprecision according to the GRADE methodology led to downgrading the levels of evidence for the prognostic factors to 'very low'.

\section{Discussion}

The present literature review, up until 9 June 2020, demonstrated that there was insufficient evidence that CVD and cardiovascular risk factors have a significant effect on poor outcome in hospitalised COVID19 patients. Studies validating prediction models for CVD are needed; once these become available, they can be added to this review of the literature.

\section{CAPACITY registry}

The same research question was also studied by the Cardiac complicAtions in Patients With SARS Corona vIrus 2 regisTrY (CAPACITY registry), an international initiative to evaluate the role of CVD in hospitalised patients with COVID-19 [11]. In August 2020, 61 hospitals from 13 countries contributed to the data collection. The data from $40 \%$ of the hospitalised Dutch patients were entered into the database and the results were published in March 2021 [12].

Data from 5500 Dutch patients were analysed to answer the research question. Basic characteristics demonstrated that patients with CVD were older and had more cardiovascular risk factors and comorbidities. They developed acute kidney injury during hospitalisation more frequently and were more often diagnosed with chronic kidney disease. Older age, male gender and frailty seemed to have predictive value.

Combining data from the Dutch CAPACITY registry [12] with those from the Lean European Open Survey on SARS-CoV-2-Infected patients (LEOSS) registry showed a significant association between New York Heart Association class III/IV heart failure and inhospital mortality for patients with cardiovascular comorbidity, after adjustment for age, gender, myocardial infarction, hypertension, chronic kidney disease, chronic obstructive pulmonary disease and diabetes mellitus. 


\section{Box 1 Recommandations}

- Regard patients with CVD and cardiovascular risk factors as vulnerable to COVID-19 and at risk of poor outcome.

- Be aware that patients with heart failure may have a greater risk of poor outcome and mortality.

- Healthcare professionals delivering care to patients with CVD should follow COVID-19 guidelines for vulnerable groups.

- Patients with CVD and cardiovascular risk factors should comply with the governmental and public health COVID-19 recommendations and advice for vulnerable groups. Implementation is expected to be high and should bear no extra costs since it is embedded in the current governmental policies.

\section{Recommendations}

In general, patients with CVD and cardiovascular risk factors are considered to be vulnerable to infectious disease outbreaks. Based on our literature review and the results from the CAPACITY registry, there is no reason not to deem them vulnerable to COVID-19. The data indicate that these patients are older and have more comorbidities and suggest that older age, male gender and frailty are predictors of mortality. Of the patients who died of COVID-19, most had a history of CVD (See Box 1).

\section{Gaps in evidence}

The initial research question remains unanswered: In which hospitalised patients with proven COVID19 and with underlying CVD and cardiovascular risk factors should doctors be alert to a poor outcome?

Funding This work was supported by the Quality Funds Foundation of Dutch Medical Specialists (Stichting Kwaliteitsgelden Medisch Specialisten).

Conflict of interest L.S.D. Jewbali, J. Hoogervorst-Schilp, E. Belfroid, C.W. Jansen, F.W. Asselbergs and H.J. Siebelink declare that they have no competing interests.

Open Access This article is licensed under a Creative Commons Attribution 4.0 International License, which permits use, sharing, adaptation, distribution and reproduction in any medium or format, as long as you give appropriate credit to the original author(s) and the source, provide a link to the Creative Commons licence, and indicate if changes were made. The images or other third party material in this article are included in the article's Creative Commons licence, unless indicated otherwise in a credit line to the material. If material is not included in the article's Creative Commons licence and your intended use is not permitted by statutory regulation or exceeds the permitted use, you will need to obtain permission directly from the copyright holder. To view a copy of this licence, visit http://creativecommons.org/licenses/by/4.0/.

\section{References}

1. Govaert TM, Thijs CT, Masurel N, Sprenger MJ, Dinant GJ, Knottnerus JA. The efficacy of influenza vaccination in elderly individuals: a randomized double-blind placebocontrolled trial. JAMA. 1994;272:1661-5.

2. Liu WM, van der Zeijst BA, Boog CJ, Soethout EC. Aging and impaired immunity to influenza viruses: implications for vaccine development. Hum Vaccin. 2011;7(Suppl):94-8.

3. Chen R, Liang W, Jiang M, et al. Risk factors of fatal outcome in hospitalized subjects with coronavirus disease 2019 from a nationwide analysis in China. Chest. 2020;158:97-105.

4. Giacomelli A, Ridolfo AL, Milazzo L, et al. 30-day mortality in patients hospitalized with COVID-19 during the first wave of the Italian epidemic: a prospective cohort study. PharmacolRes. 2020;158:104931.

5. Wang L, HeW, YuX, etal. Coronavirus disease 2019 in elderly patients: characteristics and prognostic factors based on 4-weekfollow-up. J Infect. 2020;80:639-45.

6. Cummings MJ, Baldwin MR, Abrams D, etal. Epidemiology, clinical course, and outcomes of critically ill adults with COVID-19 in New York City: a prospective cohort study. Lancet. 2020;395:1763-70.

7. Gao C, Cai Y, Zhang K, et al. Association of hypertension and antihypertensive treatment with COVID-19 mortality: a retrospective observational study. Eur Heart J. 2020;41(22):2058-2020.

8. Klang E, Kassim G, Soffer S, et al. Morbid obesity as an independent risk factor for COVID-19 mortality in hospitalized patients younger than 50. Obesity. 2020; https://doi.org/ 10.1002/oby.22913.

9. Palaiodimos L, Kokkinidis DG, Li W, et al. Severe obesity, increasing age and male sex are independently associated with worse in-hospital outcomes, and higher in-hospital mortality, in a cohort of patients with COVID-19 in the Bronx, NewYork. Metabolism. 2020;108:154262.

10. Petrilli CM, Jones SA, Yang J, et al. Factors associated with hospital admission and critical illness among 5279 people with coronavirus disease 2019 in New York City: prospective cohortstudy. BMJ. 2020;369:m1966.

11. Linschoten M, Asselbergs FW. CAPACITY-COVID: a European Registry to determine the role of cardiovascular disease in the COVID-19 pandemic. Eur Heart J. 2020;41(19):1795-6.

12. Linschoten M, Asselbergs FW. CAPACITY-COVID collaborative consortium, LEOSS Study Group. Clinical presentation, disease course and outcome of COVID-19 in hospitalized patients with and without pre-existing cardiac disease - a cohort study across sixteen countries [preprint] https://www.medrxiv.org/content/10.1101/2021. 03.11.21253106v1. 